\title{
Quality Assessment of Bread Sold in Gombi Local Government Area, Adamawa State, Nigeria
}

\author{
Priscilla Alexander Elizabeth Stephen Habila Irimiya. \\ Department of Pure and Applied Chemistry, Adamawa State University, \\ P.M.B 25 Mubi, Adamawa State, Nigeria
}

\begin{abstract}
The moisture, ash, crude fiber composition, vitamin $\left(\mathrm{B}_{2}, \mathrm{~B}_{6}\right.$ and $\left.\mathrm{B}_{12}\right)$ and mineral $(\mathrm{Na}, \mathrm{K}, \mathrm{Ca} \mathrm{Mg}, \mathrm{Pb}, \mathrm{Cd}$, $\mathrm{Mn}$ )contents as well as Sensory properties (color, taste, odour and texture)of ten brands of bread sold in Gombi Local Government Area, Adamawa State, Nigeria were determined using standard methods . Fresh loaves of ten most popular brands of bread namely:Trustee, Destiny, Ziranza, Royal and Zango, were randomly collected. Five of these brands were purchased from bakeries (coded: Aa -Ea), while others of the same brands were purchased from different points of sale (coded: Ab-Eb) within Gombi town. The results of the investigation revealed that $\mathrm{Cd}, \mathrm{Pb}$ and potassium bromate were not detected in all the samples. Potassium and sodium were predominant among all the tested samples. The moisture, ash and crude fiber contents ranged from (20.00 to $34.49 \%$ and 13.96 to $19.49 \%)$, ( 0.49 to $1.95 \%$ and 0.50 to $2.49 \%$ ), and (10.91 to 33.13 and 28.32 to $47.30 \%$ ) of samples from bakeries and points of sales, respectively. Vitamins $\mathrm{B}_{2}, \mathrm{~B}_{6}$ and $\mathrm{B}_{12}$ were non-significant differences $(p>0.05)$ in the vitamin content among the bread samples. The concentrations of all the parameters studied were all within the standard specification given by Standard Organization of Nigeria (SON) except crude fiber that is higher. This study showed that the bread brands produced in Gombi town could be nutritious, free from pollutants and suitable for human consumption.
\end{abstract}

Keywords: Bread, Gombi, proximate composition, mineral contents, and vitamins

DOI: $10.7176 / \mathrm{FSQM} / 85-07$

Publication date:March $31^{\text {st }} 2019$

\section{INTRODUCTION}

Bread is highly nutritional food eaten in one form or another by nearly every person on earth. Bread is a good source of carbohydrates and micronutrients such as vitamins and minerals (Eke et al., 2013).Bread is also an excellent source of fibre, protein and folic acid, bread has been an essential element of human diet for centuries in all regions (Eshetuet al., 2018). The simplest breads are made from grains such as wheat (Triticumaestivum),oats (Avena sativa),barley (Hordeumvulgare), rye(Secalecereal), millet (Panicummiliaceum) and corn (Zea mays)mixed or with milk or water. These ingredients are mixed in dough, shaped and baked. Salt, eggs, sugar and other ingredients may be added to give the bread flavour, change its texture or increase its nutritional value (Dooshima et al., 2014). A special ingredient called a leaving agent is often added to make the bread rise by enlarging air pockets in the dough, giving it a lighter texture and more volume (Erikssonet al., 2013). Wheat (Triticumaestivum) is the popular flour for the production of bread and especially for the production of cakes and other pastries (Olaoye et al., 2006). Although, bread is also produced, from the flour of other wheat species such as Triticum durum, Triticumdicocum and Triticumspelta as reported by Komolaga et al. (2012). According to several studies, bread is now one of the most popularly consumed foods in the worldAdebayo-Oyetoro et al. (2016). Bread has been the principal form of food for man and is also an important staple food of complex carbohydrate in the developed and developing world (Abdelghafor et al., 2011). Apart from being rich source of carbohydrates and other nutrients, wheat is known to be nutritionally poor as it is deficient in essential amino acids such as threonine and lysine. Therefore, nutritional value of wheat product should be increased by supplementation with staples such as pulses, cereals and sweet potato flours (Eriksson et al., 2013). Since wheat bread is the staple food in most regions of the world. Hence, depending its type and origin, the bread provides approximately more than $10 \%$ of individual's daily intake of protein, vitamins (e.g. thiamine, niacin), minerals (e.g. iron, zinc, copper), and required fiber (Eshetuet al., 2018). In many countries, especially in India, bread has become one of the most important popularly consumed non-indigenous food (Das et al., 2012), where as in Nigeria, bread is the most important item of breakfast among Nigerian diets. According to Shittu et al. (2007) after rice, bread is the second most largely consumed non- indigenous food in Nigeria.

Bread contains many ingredients that help to improve its quality; bread can vary in terms of their shape, volume, ingredient content, crumb texture and softness, crust thickness and crispness etc (Adebayo-Oyetoro et al., 2016). One of the major challenges in baking quality of flour is the capacity of the prepared dough to retain gas. This has become a major problem in both the flour milling industry and bakeries (Eke et al., 2013). Due to the wide variations in the composition of flour, several treatments and additives such as conditioning agents or supplements and bread improvers are added to the flour during mixing, to strength the dough, improve 
extensibility for molding and to increase the loaf volume and texture (Dooshima et al.,2014).

Several studies showed that many improvers such as potassium bromate used over the years have some deleterious effect to health, thereby necessitating their ban (Eriksson et al. 2014). Toxicological studies according to Olaoye et al. (2006), have shown that, with respect to human health, consumption of potassium bromate can lead to cancer effect, such as degrading vitamins $A_{1}, A_{2}, B_{1}, B_{2}, E$ and niacin which are the main vitamins available in bread and causing significant differences in essential fatty acid content of flour treated with bromate, causing the development of cough, sore throat, abdominal pain, diarrhea, nausea etc (Oloyede et al., 2013). Several research studies have shown that potassium bromated is carcinogenic in nature, and have the potential to cause cancer by inducing oxidative stress in the tissues of both human and experimental animals(Olaoye et al. 2006; Dooshima et al. 2014; and Eshetu et al., 2018). The aim of this study is to assess the quality of bread,by determining the physicochemical parameters, vitamins, mineral contents and as well as sensory properties of bread sold in Gombi townin Gombi Local Government area of Adamawa State, Nigeria.

\section{MATERIALS AND METHODS}

2.1.Sample collection

Ten brands of bread samples most popular, commonly consumed and produced in Gombi town in Gombi Local Government area of Adamawa State, Nigeria were randomly collected within the study area. Five brands of bread samples were collected from five different bakeries namely Trustee, Destiny, Ziranza, Royal and Zango (codedAa-Ea) and five brands of the same brands of bread samples were purchase from different points of sales such as in the market, Motor Park, tea sellers, mechanic workshops and provision shops where major commercial activities take place (coded $\mathrm{Ab}-\mathrm{Eb}$ ). These samples were analysed immediately after purchase.

\subsection{Methods of analysis}

Moisture and ash contents: Moisture and ash contents were determined according to AOAC (2005).

\subsection{Determination of fiber content}

Weende's method (James, 2013) was used for determination of fiber content. Two $g$ of each sample was weighed using analytical balance and put in to a $250 \mathrm{ml}$ round bottom flask. Then, $200 \mathrm{ml}$ of $1.25 \% \mathrm{H}_{2} \mathrm{SO}_{4} \mathrm{was}$ added and the obtained mixture was then boiled under reflux for about $30 \mathrm{~min}$. The solution was filtered with Whatman No. 52 filter paper, the residue was rinsed thoroughly with hot water until it was no more acidic when tested using universal $\mathrm{pH}$ indicator. The residue was transferred into a $250 \mathrm{ml}$ beaker and 200 $\mathrm{ml}$ of $1.25 \% \mathrm{NaOH}$ was added and boiled for $30 \mathrm{~min}$ in a digestion apparatus after which it was filtered and rinsed with distilled water until the filtrate was neutral when tested with universal $\mathrm{pH}$ indicator. The residue was transferred into a crucible and then placed in the electric oven at $100^{\circ} \mathrm{C}$ for $8 \mathrm{~h}$ to dry. It was then removed and placed in desiccators to cool before weighing. The crude fiber content was determined using equation indicated below:

Crude fiber $(\mathrm{g} / 100 \mathrm{~g})=\left[\left(\mathrm{W}_{1}-\frac{\left.\mathrm{W}_{2}\right)}{\mathrm{W}_{3}} \times 100\right]\right.$

Where: $\mathrm{W}_{1}=$ weight of (crucible + sample) after drying; $\mathrm{W}_{2}=$ weight of (crucible + sample) after ashing; $\mathrm{W}_{3}=$ weight of fresh sample.

\subsection{Determination of mineral content}

Mineral contents of bread were determined after digestion using dry ashing method following the method reported by $\mathrm{AOAC}$ (2005). To the digested filtrate, $2 \mathrm{ml}$ of concentrated $\mathrm{HCl}, 10 \mathrm{~mL}$ of $20 \% \mathrm{HNO}_{3}$ were added, evaporated on the hot plate. $50 \mathrm{ml}$ of distilled water was added and was filtered through WhatmanNo.1 filter paper into $50 \mathrm{ml}$ volumetric flask. The mineral elements and the heavy metals were determined by atomic absorption spectroscopy (Buck Scientific 210 model, (Scotland), while sodium and potassium was determined using flame photometer (Sherwood Scientific 410 Model, (UK). For each element, calibration curves were constructed using standard concentrations of each element.

\subsection{Physical Determination}

The sensory evaluation of the breads for texture, taste, aroma, and colour, were determined according to (Ihekoronye and Ngoddy, 1985).1g of the bread sample was heated on a hot plate and the aroma was perceived. The texture of each sample was determined by hand feel using the thumb and fore- finger (Ihekoronye and Ngoddy, 1985).

\subsection{Determination of Vitamins}

Vitamins $\mathrm{B}_{2}, \mathrm{~B}_{6}$ and $\mathrm{B}_{12}$ were determined using High Performance Liquid Chromatography (HPLC) (Buck Scientific (USA) BLC10/11 - Model) (AOAC, 2005). 


\subsection{Detection of potassium bromate in bread samples}

Potassium Bromate was determined by qualitative method as described by AOAC (2005). $7 \mathrm{~cm}^{3}$ of $1 \% \mathrm{KI}$ solution was pipette into a beaker and $1 \mathrm{~cm}^{3}$ of $\mathrm{HCl}$ was added to it, then $4 \mathrm{~g}$ of the sieved powdered sample was evenly distributed into it until all the powdered bread sample was wetted by the reagent. The presence of black specks or purple spots indicated the presence of potassium bromated, otherwise, it was absent.

\subsection{Statistical analysis}

All analysis was conducted in triplicate determinations and results were presented as mean and standard deviation.

\section{RESULTS AND DISCUSSION}

All the bread samples were white in colour except sample coded "Db" which had chocolate colour, they all have sweet aroma and taste. The white colour of the bread may be due to the wheat used and the efficiency of the milling system and also may be attributed to the use of bleaching agents. Bleaching, changes the colour of the wheat flour by oxidizing the caroteniod pigments in the endosperm, and the colouring matter from the ban (Alexander and Ndukwe, 2010). All the bread samples has sweet aroma on heating, possibly due to the released of volatile flavouring compounds or maillard reaction (Ihekoronye and Ngoddy (1985).

However, presence of sugars in flour is very important for the growth of yeast during fermentation and also their presence determined the gassing property of the flour. Samples coded "Ab", "Cb", "Db", "Aa", "Ca", and "Da" were soft and consistent while samples coded "Bb", "Eb", "Ba" and "Ea" were soft and crumbly (crisp) Begum et al. (2014). The addition of small quantity of sodium chloride during mixing gives taste and imparts flavour Eriksson et al. (2014).

\subsection{Moisture, Ash, crude fiber and Mineralprofiles}

The results of moisture, ash, and crude fiber contents, as well as mineral profiles of the selected bread samples from the bakeries and points of sales are as presented in Tables 1 and 2.There were significant differences $(\mathrm{p}<0.05)$ in the moisture, crude fibre, and ash contents of the bread samples. These values fall within the ranges permitted by SON (2004) except for crude fiber which was higher. The moisture content of (20.00 to $34.49 \%$ and 13.96 to $19.49 \%$ ), compared to the maximum value of $40.00 \%$ specified by SON and this is comparable to the amount in bread flour 13.9 to $15.0 \%$ and also is in agreement with the findings of Olaoye and Onilude (2011); Adebayo-Oyetoro et al. (2016). However, all the samples falls within the standard limit range of Standard Organization of Nigeria (SON, 2004) $10-40 \%$ for white bread. The moisture content of foods is usually used as an indicator of food quality. It is important to measure the moisture content in breads because of its potential impact on the sensory, physical and microbial properties of the bread Olaoyeet al. (2006); AdebayoOyetoro et al. (2016). It was noted that as the substitution level increases the moisture content also increases (Ayub et al., 2003).

The ash contents of the samples from the bakeries and points of sale ranged from 0.49 to $1.95 \%$ and 0.5 to $2.49 \%$ respectively, this was in agreement to the findings of Olaoye et al. (2006); Mongi et al. (2011); Eshetu et al. (2018). These values were within the standard specification of (SON, 2004) for ash content of wheat flour $(0.60$ to $1.10 \%)$ and wheat grain $(0.4$ to $1.0 \%)$. The result showed no significant difference between the ash content of the samples from the bakeries and those from points of sale.

The crude fiber of the bread samples ranges from $10.91 \pm 0.04 \%$ to $33.13 \pm 0.01 \%$ and $28.32 \pm 0.08$ to $47.30 \pm 0.14 \%$ from bakeries and points of sales, respectively. These values are higher than the standard limit 0.5 to $6.0 \%$ of SON (2004). It was observed that the crude fibre was the highest in samples $\mathrm{Cb}(47.30 \pm 0.14 \%)$; Eb $(39.68 \pm 0.11 \%) ; \mathrm{Db}(36.70 \pm 0.18 \%) ; \mathrm{Da}(33.13+0.01 \%) ;$ and $\mathrm{Ea}(28.00 \pm 0.01 \%)$, respectively; samples from points of sales recorded higher values than samples from bakeries (Tables 1 and 2). However, the values recorded in this study were higher than those reported by Olaoye et al.(2006) and Eke et al.(2013).

3.2. Mineral profile: Results of the mineral composition of the ten selected bread samples are as presented in Tables 1 and 2. Calcium, magnesium, sodium, and potassium were found in all the bread brands. There were no significant differences in the mineral values among the bread samples. This is contrary to the reports of Ebuehi et al. (2007) and Dooshima et al. (2014) with bread samples in Lagos, Benue and Nassrawa metropolis in Nigeria.

The metabolic functions of minerals for life cannot be overemphasized and has been extensively reported in literature Eke et al. (2013). The calcium content of breads from different bakeries and points of sales ranged from 5.10 to $5.70 \%$. Compared with the (WHO/FAO, 2011) $(18 \mathrm{mg} / \mathrm{kg})$, the breads investigated in this study were found to contain lower calcium content and hence did not meet the bread quality standards in this respect. Calcium is an important constituent of body fluids and bone formation in conjunction with phosphorus (Olaoye et al., 2006). Calcium also plays a major role in nutrition including bone formation, maintenance and growth, 
tooth formation, blood clot formation, absorption of vitamin B12 and contraction of muscles. Calcium is necessary for supporting bone formation and growth (Eriksson et al., 2014). Generally the entire bread samples studied, had their calcium values lower compare to WHO/FAO standard limits $(18 \mathrm{mg} / 100 \mathrm{~g})$. The results revealed that there is no significance difference $(p>0.05)$ in the calcium contents of the bread samples from bakeries and those from points of sales.

The values of magnesium in all the studied bread samples ranged from 0.60 to $1.20 \%$ and 0.03 to $1.20 \%$ of breads from bakeries and point of sales respectively. These values were very low compared to the standard values recommended by WHO/FAO (2011) $(31 \mathrm{mg} / \mathrm{kg})$. The results also revealed that the magnesium contents were less than those of calcium in all the studied bread samples. The fortification of flour contributes $14 \%$ of the total calcium intake for adults and almost $20 \%$ for children (O’Connor, 2012).

The concentration of sodium recorded in this study ranges from 31.50 to $62.70 \%$ and 61.50 to $75.30 \%$ of the bread samples from bakeries and points of sales, respectively. An adult needs about $3 \mathrm{~g}$ per day of $\mathrm{Na}$ but modern dietary habits can take in 5-20g per day (Odedeji et al., 2014). These values fall within the standard values recommended by $\mathrm{WHO} / \mathrm{FAO}$

The potassium content in this investigation ranged from 45.00 to $60.00 \%$ in bread samples from bakeries and 61.50 to $75.30 \%$ in samples from other points of sales. This result is in agreement with the findings of Odedeji et al.(2014); Adebayo-Oyetoro et al.(2016) and Eshetu et al.(2018).

3.3.Vitamin content: Tables 3 and 4 presented the vitamins $\left(B_{2}, B_{6}\right.$ and $\left.B_{12}\right)$ contents of the selected bread samples. There was no significant differences $(p>0.05)$ in the vitamin contents among the bread samples from the bakeries and points of sales, and this results are in agreement to the findings of Eke et al.(2014) and also are within the standard specification of (SON, 2004).

3.4.Pollutants or Hazardous materials: The results of heavy metals and potassium bromate are presented in Tables 5 and 6 . The results of the investigation carried out showed that all the bread samples studied were free of potassium bromate.

Cadmium and Lead were not detected in all the bread samples analyzed and this is very commendable. All the bread samples studied have their manganese values within WHO/FAO standard values $(1-3 \%)$.

\section{CONCLUSION}

This study has shown that calcium, potassium, sodium, magnesium and vitamins $\mathrm{B}_{2}, \mathrm{~B}_{6}$ and $\mathrm{B}_{12}$ were present in the studied bread samples. The study also revealed that there was free potassium bromate in all the studied bread samples. Heavy metals were also determined; $\mathrm{Pb}$ and $\mathrm{Cd}$ were not detected, which is a very good development. Bakers are therefore advised to fortify their products in order to meet the expected standard. It has been observed that the bread samples studied from the bakeries contained more moisture than the bread obtained from different points of sales. This might be as a result of long time exposure of bread at the points of sales. This study showed that the bread brands sold in Gombi town could be nutritious, free from pollutants and suitable for human consumption.

Table 1: Some Characteristics of Bread samples from Bakeries

\begin{tabular}{|c|c|c|c|c|c|c|c|c|}
\hline Samples & Texture & Moisture (\%) & Ash (\%) & Crude Fiber (\%) & $\begin{array}{l}\begin{array}{l}\text { Magnesium } \\
(\mathrm{mg} / 100 \mathrm{~g})\end{array} \\
\end{array}$ & $\begin{array}{l}\text { Calcium } \\
(\mathrm{mg} / 100 \mathrm{~g})\end{array}$ & $\begin{array}{l}\text { Potassium } \\
(\mathrm{mg} / 100 \mathrm{~g})\end{array}$ & $\begin{array}{l}\begin{array}{l}\text { Sodium } \\
(\mathrm{mg} / 100 \mathrm{~g})\end{array} \\
\end{array}$ \\
\hline $\mathrm{Aa}$ & Soft and consistent & $34.49 \pm 0.02$ & $1.98 \pm 0.02$ & $10.91 \pm 0.40$ & $0.60 \pm 0.01$ & $5.4 \pm 0.20$ & $\begin{array}{l}16.8 \\
0.20\end{array}$ & $31.5 \pm 0.20$ \\
\hline $\mathrm{Ba}$ & Soft and Crumble & $26.00 \pm 0.01$ & $1.95 \pm 0.01$ & $23.02 \pm 0.02$ & $1.2 \pm 0.02$ & $5.7 \pm 0.20$ & $45 \pm 0.20$ & $61.8 \pm 0.10$ \\
\hline $\mathrm{Ca}$ & Soft and Consistent & $21.00 \pm 0.01$ & $0.49 \pm 0.01$ & $20.95 \pm 0.05$ & $0.6 \pm 0.01$ & $5.7 \pm 0.10$ & $30 \pm 0.10$ & $60.3 \pm 0.10$ \\
\hline $\mathrm{Da}$ & Soft and Consistent & $20.00 \pm 0.01$ & $1.50 \pm 0.01$ & $33.13 \pm 0.01$ & $1.2 \pm 0.02$ & $5.1 \pm 0.20$ & $60 \pm 0.20$ & $62.7 \pm 0.10$ \\
\hline $\mathrm{Ea}$ & Soft and Crumble & $27.99 \pm 0.01$ & $1.00 \pm 0.01$ & $28.00 \pm 0.01$ & $0.30 \pm 0.01$ & $5.4 \pm 0.20$ & $30 \pm 0.20$ & $61.5 \pm 0.10$ \\
\hline Range & & $\begin{array}{l}20.00 \pm 0.01- \\
34.49 \pm 0.02\end{array}$ & $\begin{array}{l}0.49 \pm 0.01- \\
1.95 \pm 0.01\end{array}$ & $\begin{array}{l}10.91 \pm 0.40- \\
33.13 \pm 0.01\end{array}$ & $\begin{array}{l}0.60 \pm 0.01- \\
1.2 \pm 0.02\end{array}$ & $\begin{array}{l}5.1 \pm 0.20- \\
5.7 \pm 0.20\end{array}$ & $\begin{array}{l}30 \pm 0.10- \\
60 \pm 0.20\end{array}$ & $\begin{array}{l}31.5 \pm 0.20- \\
62.7 \pm 0.10\end{array}$ \\
\hline SON & & $10-40 \%$ & $0.6-.1 .10 \%$ & $0.5-6 \%$ & & & & \\
\hline $\mathrm{WHO} / \mathrm{FAO}$ & & & & & $31 \mathrm{mg} / \mathrm{kg}$ & $18 \mathrm{mg} / 100 \mathrm{~g}$ & & $250 \mathrm{mg} / 100 \mathrm{~g}$ \\
\hline
\end{tabular}

Values are means \pm SD of triplicate determinations. Key: $\mathrm{Aa}=$ Trustee, $\mathrm{Ba}=$ Destiny, $\mathrm{Ca}=\mathrm{Ziranza}, \mathrm{Da}=$ Royal, Ea = Zango 
Table 2: Some characteristics of Bread samples from Points of sales

\begin{tabular}{|c|c|c|c|c|c|c|c|c|}
\hline Samples & Texture & Moisture \% & Ash \% & $\begin{array}{l}\text { Crude fiber } \\
\%\end{array}$ & $\begin{array}{l}\text { Magnesium } \\
\mathrm{mg} / 100 \mathrm{~g}\end{array}$ & $\begin{array}{l}\text { Calcium } \\
\mathrm{mg} / 100 \mathrm{~g}\end{array}$ & $\begin{array}{l}\text { Potassium } \\
\mathrm{mg} / 100 \mathrm{~g}\end{array}$ & $\begin{array}{l}\text { Sodium } \\
\mathrm{mg} / 100 \mathrm{~g}\end{array}$ \\
\hline $\mathrm{Ab}$ & $\begin{array}{l}\text { Soft and } \\
\text { Consistent }\end{array}$ & $19.49 \pm 0.01$ & $0.98 \pm 0.02$ & $28.32 \pm 0.08$ & $0.60 \pm 0.01$ & $5.4 \pm 0.20$ & $16.8 \pm 0.20$ & $31.5 \pm 0.20$ \\
\hline $\mathrm{Bb}$ & $\begin{array}{l}\text { Soft and } \\
\text { Crumble }\end{array}$ & $14.46 \pm 0.16$ & $0.5 \pm 0.03$ & $29.50 \pm 0.02$ & $1.2 \pm 0.02$ & $5.7 \pm 0.20$ & $45 \pm 0.20$ & $61.8 \pm 0.10$ \\
\hline $\mathrm{Cb}$ & $\begin{array}{l}\text { Soft and } \\
\text { Consistent }\end{array}$ & $13.96 \pm 0.06$ & $2.49 \pm 0.01$ & $47.30 \pm 0.14$ & $0.6 \pm 0.01$ & $5.7 \pm 0.10$ & $30 \pm 0.10$ & $60.3 \pm 0.10$ \\
\hline $\mathrm{Db}$ & $\begin{array}{l}\text { Soft and } \\
\text { Consistent }\end{array}$ & $14.50 \pm 0.02$ & $1.45 \pm 0.01$ & $36.70 \pm 0.18$ & $1.2 \pm 0.02$ & $5.1 \pm 0.20$ & $60 \pm 0.20$ & $62.7 \pm 0.10$ \\
\hline $\mathrm{Eb}$ & $\begin{array}{l}\text { Soft and } \\
\text { Crumble }\end{array}$ & $14.50 \pm 0.01$ & $1.47 \pm 0.03$ & $39.68 \pm 0.11$ & $0.30 \pm 0.01$ & $5.4 \pm 0.20$ & $30 \pm 0.20$ & $61.5 \pm 0.10$ \\
\hline Range & & $\begin{array}{l}13.96 \pm 0.06-19.49 \pm \\
0.01\end{array}$ & $\begin{array}{l}0.5 \pm 0.03 \\
2.49 \pm 0.01\end{array}$ & $\begin{array}{l}28.32 \pm 0.08- \\
47.30 \pm 0.14\end{array}$ & $\begin{array}{l}0.60 \pm 0.01- \\
1.2 \pm 0.02\end{array}$ & $\begin{array}{l}5.1 \pm 0.20- \\
5.7 \pm 0.20\end{array}$ & $\begin{array}{l}30 \pm 0.10 \\
60 \pm 0.20\end{array}$ & $\begin{array}{l}31.5 \pm 0.20 \\
62.7 \pm 0.10\end{array}$ \\
\hline SON & & $10-40 \%$ & $0.60-1.10 \%$ & $0.5-6 \%$ & & & & \\
\hline
\end{tabular}
$31 \mathrm{mg} / \mathrm{kg} \quad 18 \mathrm{mg} / 100 \mathrm{~g} \quad 3.5 \mathrm{~g}(350 \%) \quad 250 \mathrm{mg} / 100 \mathrm{~g}$ Values are means \pm S.D. of triplicate determinations; Key: $\mathrm{Ab}=$ Trustee, $\mathrm{Bb}=$ Destiny, $\mathrm{Cb}=$ Ziranza, $\mathrm{Db}=$ Royal, $\mathrm{Eb}=$ Zango

Table 3: Vitamin contents (mg/100g) of Bread samples from Bakeries

\begin{tabular}{llll} 
Samples & $\mathrm{B}_{2}$ & $\mathrm{~B}_{6}$ & $\mathrm{~B}_{12}$ \\
\hline & & & \\
$\mathrm{Aa}$ & $1.03 \pm 0.07$ & $0.99 \pm 0.07$ & $0.72 \pm .0 .01$ \\
$\mathrm{Ba}$ & $1.23 \pm 0.07$ & $1.58 \pm 0.07$ & $0.83 \pm 0.01$ \\
$\mathrm{Ca}$ & $1.04 \pm 0.07$ & $0.98 \pm 0.07$ & $0.96 \pm 0.01$ \\
$\mathrm{Da}$ & $0.78 \pm 0.07$ & $1.21 \pm 0.01$ & $0.63 \pm 0.01$ \\
$\mathrm{Ea}$ & $0.89 \pm 0.07$ & $1.11 \pm 0.07$ & $0.72 \pm 0.01$ \\
$\mathrm{Range}$ & $0.78 \pm 0.07-$ & $0.96 \pm 0.07-$ & $0.63 \pm 0.01-$ \\
& $0.89 \pm 0.07$ & $1.58 \pm 0.07$ & $0.96 \pm 0.01$ \\
SON & $0.06-1.7$ & $0.33-2.0$ & $0.006-0.99$ \\
\hline
\end{tabular}

Values are means $\pm \mathrm{SD}$ of triplicate determinations, Key: $\mathrm{Ab}=$ Trustee, $\mathrm{Bb}=$ Destiny, $\mathrm{Cb}=\mathrm{Ziranza}, \mathrm{Db}=$ Royal, Eb = Zango

Table 4: Vitamin contents $(\mathrm{mg} / 100 \mathrm{~g})$ of Bread samples from points of sales

\begin{tabular}{llll}
\hline Samples & $\mathrm{B}_{2}$ & $\mathrm{~B}_{6}$ & $\mathrm{~B}_{12}$ \\
\hline $\mathrm{Ab}$ & $1.23 \pm 0.012$ & & \\
$\mathrm{Bb}$ & $1.35 \pm 0.007$ & $1.34 \pm 0.01$ & $0.69 \pm 0.001$ \\
$\mathrm{Cb}$ & $0.99 \pm 0.007$ & $1.62 \pm 0.01$ & $0.95 \pm 0.007$ \\
$\mathrm{Db}$ & $1.21 \pm 0.001$ & $1.45 \pm 0.01$ & $0.93 \pm 0.007$ \\
$\mathrm{~Eb}$ & $0.98 \pm 0.007$ & $0.96 \pm 0.07$ & $0.86 \pm 0.001$ \\
$\mathrm{Range}$ & $0.98 \pm 0.007-$ & $1.72 \pm 0.07$ & $0.97 \pm 0.007$ \\
& $1.35 \pm 0.007$ & $0.96 \pm 0.07-$ & $0.69 \pm 0.001-$ \\
$\mathrm{SON}$ & $0.06-1.7$ & $1.72 \pm 0.07$ & $0.97 \pm 0.007$ \\
\hline
\end{tabular}

Values are means $\pm \mathrm{SD}$ of triplicate determinations, Key: $\mathrm{Ab}=$ Trustee, $\mathrm{Bb}=$ Destiny, $\mathrm{Cb}=\mathrm{Ziranza}, \mathrm{Db}=$ Royal, Eb = Zango

Table 5: Occurrence of Heavy Metals and Potassium Bromate in Bread Samples from Bakeries (\% dry wt)

\begin{tabular}{|c|c|c|c|c|}
\hline Bread samples & Cadmium & Lead & Manganese & Potassium Bromate \\
\hline $\mathrm{Aa}$ & ND & ND & $2.5 \pm 0.10$ & Absent \\
\hline $\mathrm{Ba}$ & ND & ND & $2.5 \pm 0.20$ & Absent \\
\hline $\mathrm{Ca}$ & ND & ND & $3.4 \pm 0.20$ & Absent \\
\hline $\mathrm{Da}$ & ND & ND & $3.5 \pm 0.10$ & Absent \\
\hline $\mathrm{Ea}$ & ND & ND & $2.5 \pm 0.20$ & Absent \\
\hline Range & & & $\begin{array}{l}2.5 \pm 0.20- \\
3.5 \pm 0.10\end{array}$ & \\
\hline WHO/FAO & $0.5 \mathrm{mg} / \mathrm{kg}(0.05 \%)$ & $2 \mathrm{mg} / \mathrm{kg}(0.2 \%)$ & $10-30 \mathrm{mg} / \mathrm{kg}(1-3 \%$ & \\
\hline
\end{tabular}


Table 6: Occurrence of Heavy Metals and Potassium Bromate in Bread Samples from points of sales (\% dry wt)

\begin{tabular}{lllll}
\hline Bread samples & Cadmium & Lead & Manganese & Potassium Bromate \\
\hline & & & & \\
$\mathrm{Ab}$ & $\mathrm{ND}$ & $\mathrm{ND}$ & $3.4 \pm 0.20$ & Absent \\
$\mathrm{Bb}$ & $\mathrm{ND}$ & $\mathrm{ND}$ & $3.4 \pm 0.20$ & Absent \\
$\mathrm{Cb}$ & $\mathrm{ND}$ & $\mathrm{ND}$ & $3.4 \pm 0.30$ & Absent \\
$\mathrm{Db}$ & $\mathrm{ND}$ & $\mathrm{ND}$ & $3.5 \pm 0.10$ & Absent \\
$\mathrm{Eb}$ & $\mathrm{ND}$ & & $2.5 \pm 0.20$ & Absent \\
Range & & $2.5 \pm 0.20-$ & \\
& & $3.5 \pm 0.10$ & \\
WHO/FAO & & $10-30 \mathrm{mg} / \mathrm{kg}(1-3 \%)$ & \\
\hline
\end{tabular}

Values are means \pm S.D. of triplicate determinations. $\mathrm{ND}=$ not detected, Key: $\mathrm{Ab}=$ Trustee, $\mathrm{Bb}=\mathrm{Destiny}, \mathrm{Cb}=$ Ziranza, $\mathrm{Db}=$ Royal, Eb = Zango

\section{REFERENCES}

AbdelghaforRF, Mustafa AI, Ibrahim AMH, Krishnan PG (2011). Quality of bread from composite flour of sorghum, hard white and winter wheat. Advanced Journal of Food Science and Technology3: 9-15..

Adebayo-Oyetoro AO, OgundipeOO, andNojeemdeenK. (2016). Quality assessment and consumer acceptability of bread from wheat and fermented banana flour. Journal of Food Science andNutrition 4(3): 364-369.

AOAC (Association of Official Analytical Chemists) (2005).Official methods of analysis. $18^{\text {th }}$ Edition, AOAC International Publisher, Washington DC.

AlexanderP and Ndukwe GI (2010). Quality of Bread consumed in Yola and Jalingo Metropolis, in North Eastern Nigeria. ANACHEM. 4 (2): 478-889.

Ayub M, WahabS, Durrani Y (2003). Effect of water activity (aw), moisture content and total microbial count on the overall quality of bread. International Journal of Agriculture and Biology, 5: 274-278.

Begum R,Uddin MJ, Rahman MA, Islam MS (2014). Comparative study on the development of maize flour based composite bread. Journal of the Bangladesh Agricultural University, 11: 133-139.

Das L, Raychaudhri U, Chakraborty R (2012).Effects of baking conditions on the physical properties of herb bread using RSM.International Journal of Food, Agriculture and Veterinary Science, 2:106-114.

Ebuehi OAT, Owolabi OO, Ikanone CE,Amabibi ITT,Ajekwu AP (2007). Organoleptic, mineral and vitamin evaluation of some Nigeria bread. Nigeria Food Journal, 25(2): 95-100.

Eke MO,Ariahu CC,Gernah DI(2013). Chemical and Sensory Evaluation of Bread Sold in Benue andNasarawa States of Central Nigeria. Advanced Journal of Food Science and Technology, 5(5): 547-550.

Eriksson E, Koch K, Tortoe C, Akonor PT,Baidoo E (2013). Physicochemical, Functional and pasting characteristics of three varieties of cassava in wheat composite flours. British Journal of Applied Science and Technology, 4 (11):1609-1621

Eriksson E, Koch K, Tortoe C, Akonor PT, Oduro-Yeboah C (2014). Evaluation of the physical and sensory characteristics of bread produced from three varieties of cassava and wheat composite flours. Food and Public Health, 4(5): 214-222.

Eshetu M, Atlabachew M, Abebe A (2018). Quality Assessment of Wheat Bread Baked in Bahir Dar City, Ethiopia. Journal of Food Quality and Hazards Control, 5: 77-80.

Dooshima IB, Julius A, Abah O(2014). Quality Evaluation of Composite Bread produced from wheat, defatted soy and banana flours. International Journal of Nutrition and Food Sciences, 3(5): 471-476.

Ihekoronye AI,Ngoddy PO (1985). Integrated Food Science and Technology for the Tropics.Macmillan publishers, NewYork.Pp 296-301

James CS (Ed.) (2013). Analytical Chemistry of foods.Springer, USA.

Komolaga GA,Glover-Amengor M, DziedzoaveNT, Hagan LL (2012).Consumer acceptability of wheat cassava composite bread.World Rural Observation,4: 78-81.

Mongi RJ, Ndabikunze BK, Chove BE, Mamiro P, Ruhembe CC,NtwenyaJG (2011). Proximate composition, bread characteristics and sensory evaluation of cocoyam-wheat composite breads African Journal of Food, Agricultural and Nutrition Development, 11(7): 16-24.

O'Connor A (2012). An overview of the role of bread in the UK diet. Nutrition Bulletin, 37: 193-212.

Odedeji JO, Ojo A, Arogundade LA, OyelekeGO(2014). Proximate composition and consumers acceptability of bread produced from blends of soy-cheese and wheat flour. IOSR Journal of Environmental Science, Toxicology and Food Technology,8: 2319-2399.

Olaoye OA, Onilude AA,IdowuOA(2006). Quality characteristics of bread produced from composite flours of 
wheat, plantain and soybeans. African Journal of Biotechnology, 5(11): 1102-1106.

Olaoye OA,Onilude AA (2011).Microbiological, proximate analysis and sensory evaluation of baked products from blends of wheat- breadfruitflours.African Journal of Food, Agricultural and Nutritional Development, 8:1-12.

Oloyede OO, OchemeOB, Nurudeen LM (2013). Physical, sensory and microbiological properties of wheatfermented unripe plantain flour. Nigeria Food Journal, 31:123-129.

Shittu TA, Raji AO, Sanni LO (2007). Bread from composite cassava wheat flour: I. Effect of baking time and temperatureon some physical properties of bread loaf.Food ResourceIntergrated, 40: 280-290.

Standards Organization of Nigeria (SON) (2004). Standard onwhole wheat bread: Standards Organization of Nigeria, ICS67.060, NIS 470.

World Health Organization/Food Agricultural Organization (WHO/FAO) (2011). Joint WHO/FAO Food standard Programme Codex Committee on Contaminants in food FAO/WHO, Netherland 